\title{
Quantification of skeletal asymmetries in normal adolescents: cone-beam computed tomography analysis
}

\author{
Derek A Sanders ${ }^{1}$, Taranpreet K Chandhoke ${ }^{2 *}$, Flavio A Uribe ${ }^{2}$, Paul H Rigali ${ }^{3}$ and Ravindra Nanda ${ }^{4}$
}

\begin{abstract}
Background: The detection and quantification of skeletal asymmetries is a fundamental component to diagnosis and treatment planning in orthodontics. The purpose of this study was to identify and quantify the characteristics of facial and dental asymmetries in a normal, adolescent population using 3D imaging.

Methods: Thirty consecutive Class I patients (mean age 14.32 years, SD 1.67) meeting the inclusion criteria were analyzed by three-dimensional cone-beam computed tomography (CBCT). Dental, maxillary, mandibular, and cranial base variables were measured with Dolphin 3D. CBCT analysis consisted of the localization of 34 anatomical landmarks. All reference points were digitized in 3D and analyzed using 67 skeletal and dental measurements. Student's $t$ tests for paired samples were used with a significance level of $p<0.05$.

Results: Minor right-left discrepancies were noted in all planes. The most anterior point of the glenoid fossa and most condylar points were positioned more superior and lateral on the right side, compared to the left side. Porion was also located more superiorly on the right side relative to the left side. The posterior nasal spine was found to be located to the right of the midsagittal plane. Slight dental midline discrepancies were found, and the dental arch lengths were slightly longer on the left side compared to the right. The height of the ramus, in both $3 \mathrm{D}$ and 2D, and the inclination of the ramus were greater on the right than that on the left side.

Conclusions: The findings of this study suggest minor asymmetries exist and are likely a common occurrence in the normal human craniofacial complex. Additionally, a natural compensatory mechanism may exist which controls the size and shape of specific tissues in order to maintain functional symmetry.
\end{abstract}

\section{Background}

Dentofacial asymmetries can pose a significant challenge to orthodontic treatment and an accurate diagnosis is key to localize the asymmetry and determine the best treatment strategy. Severe forms of dentofacial deformities, such as those caused by syndromes like hemifacial microsomia, cleft palate, or hemimandibular hyperplasia, have been well described in the literature [1-3]. However, minor asymmetries are significantly more common in the general population but have not been studied as extensively. Asymmetries have been traditionally diagnosed through the analysis of postero-anterior (PA) X-rays,

\footnotetext{
* Correspondence: chandhoke@uchc.edu

${ }^{2}$ Division of Orthodontics, Department of Craniofacial Sciences, University of Connecticut, School of Dental Medicine, 263 Farmington Avenue, Farmington CT 06030, USA

Full list of author information is available at the end of the article
}

photographs and dental models [2,4,5]. Radiographs offer the benefit of measuring the skeletal component of an asymmetry, but 2D images, like PA cephalograms, are limited due to the presence of numerous artifacts, overlapping structures and magnification distortion [6,7]. The advent of three-dimensional imaging through cone-beam computed tomography (CBCT) offers the possibility of accurate localization and quantification of asymmetries without distortion. In patients with significant mandibular asymmetry, $\mathrm{CBCT}$ has been employed to quantify the degree of asymmetry with a high degree of accuracy compared to two-dimensional images [8-11]. No studies have yet been published with normative 3D values of asymmetry for patients with normal occlusions. The purpose of this study was to identify and quantify dentofacial asymmetries in a normal, adolescent population.

\section{实}




\section{Methods}

\section{Subjects}

This study was conducted in accordance with a protocol approved by the Institutional Review Board of the University of Connecticut (IRB \#08-298-1). CBCT scans and records from two orthodontic offices (Dr. Rigali and Dr. Roy) that routinely use 3D imaging for comprehensive orthodontic diagnosis and treatment planning were reviewed. CBCT images, clinical examination records, dental models, and photographs were reviewed and subjects were selected based on the following inclusion criteria: (1) Class I molar relationship, (2) teeth in occlusion from second molar to second molar, (3) no malformed or missing teeth, (4) coincident dental and facial midlines, (5) no dental or skeletal asymmetries on clinical exam, (6) no previous orthodontic treatment, (7) no crossbites, (8) no history of facial trauma or medical conditions that may have altered growth, (9) symmetrical spacing or crowding up to $3 \mathrm{~mm}$ per arch, (10) age from 10 to 18 . The final study sample was determined by two investigators (PHR and DS) and consisted of 30 consecutive patients (16 boys, 14 girls) with an average age of 14.32 years (SD 1.67 years). The sample included 28 Caucasians, 1 Asian, and 1 African-American. Figure 1 shows volumetric frontal views for each patient included in this study.

\section{CBCT acquisition}

Full-head CBCT scans (i-CAT Classic, Imaging Sciences International, Hatfield, PA, USA) were acquired with patients in maximum intercuspation. A $16.0 \mathrm{~cm}$ (diameter) $\times$ 13.0 to $22.0 \mathrm{~cm}$ (height) field of view at a resolution of $0.4 \mathrm{~mm}$ voxels was used for each volumetric data set with an acquisition setting of $120 \mathrm{kVp}$ and $5 \mathrm{~mA}$ based on the manufacturer's specifications. The scan times ranged from $20(13.0 \mathrm{~cm})$ to $40 \mathrm{~s}(22.0 \mathrm{~cm})$ depending on the vertical height of the field of view selected by the clinician based on patient factors like the skull size and height. Reconstructed data (by Xoran i-CAT software, version 2.1.22) was exported as a 12-bit-depth digital imaging and communications in medicine (DICOM) file. Final analysis of the DICOM data was completed using Dolphin 3D (version 10.5, Dolphin Imaging, Chatsworth, CA, USA).

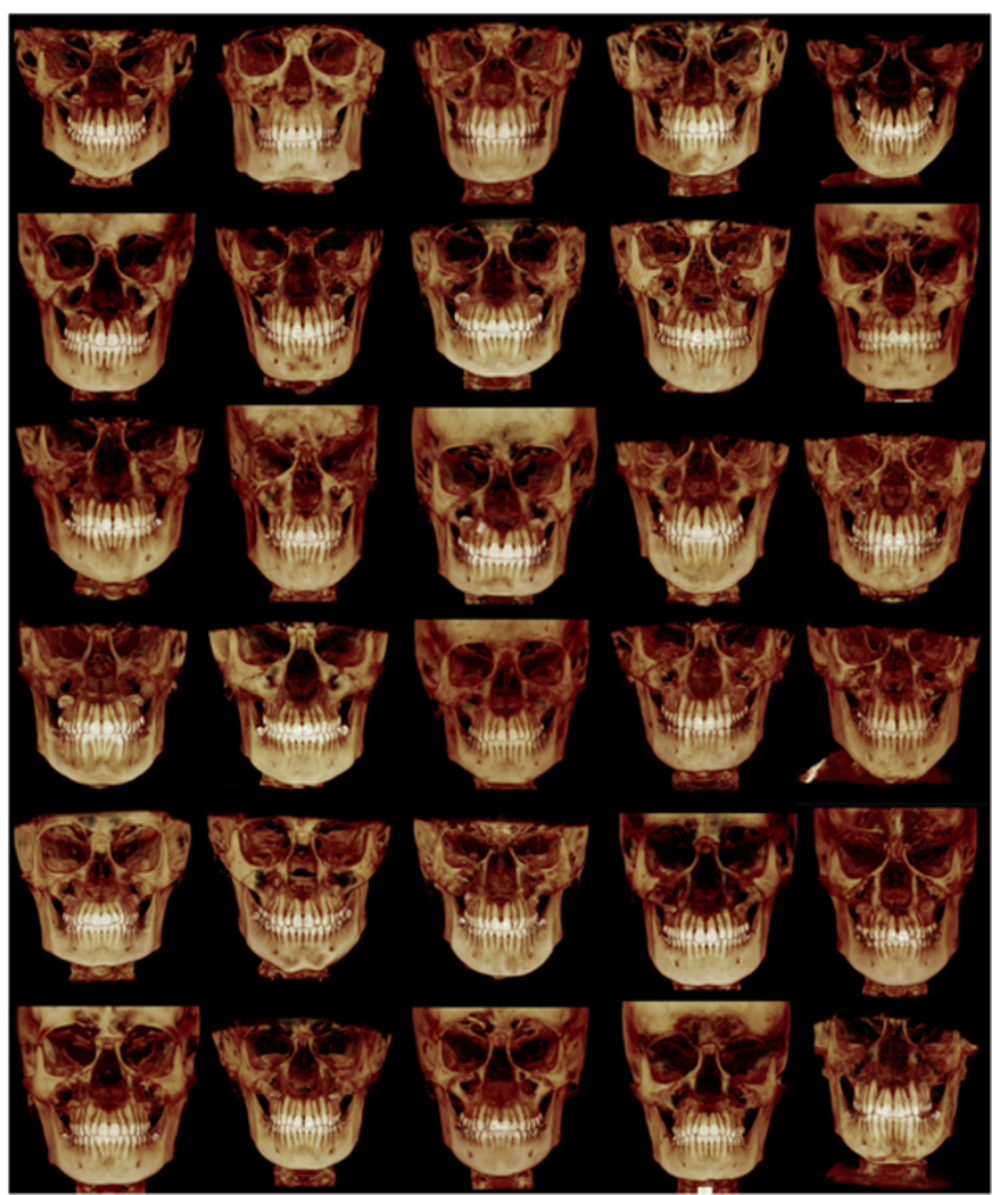

Figure 1 Volumetric images of each of the 30 Class I subjects included in the study. 


\section{CBCT orientation and landmark identification}

Orientation of each data set was completed in three planes of space $(x, y$, and $z$ ) using volumetric rendering and multiple planar views within Dolphin 3D (Figure 2). First, the sagittal plane $(x)$ was constructed bisecting paired midfacial anatomic structures (i.e., orbits, frontal process of the maxilla, and frontozygomatic suture). The

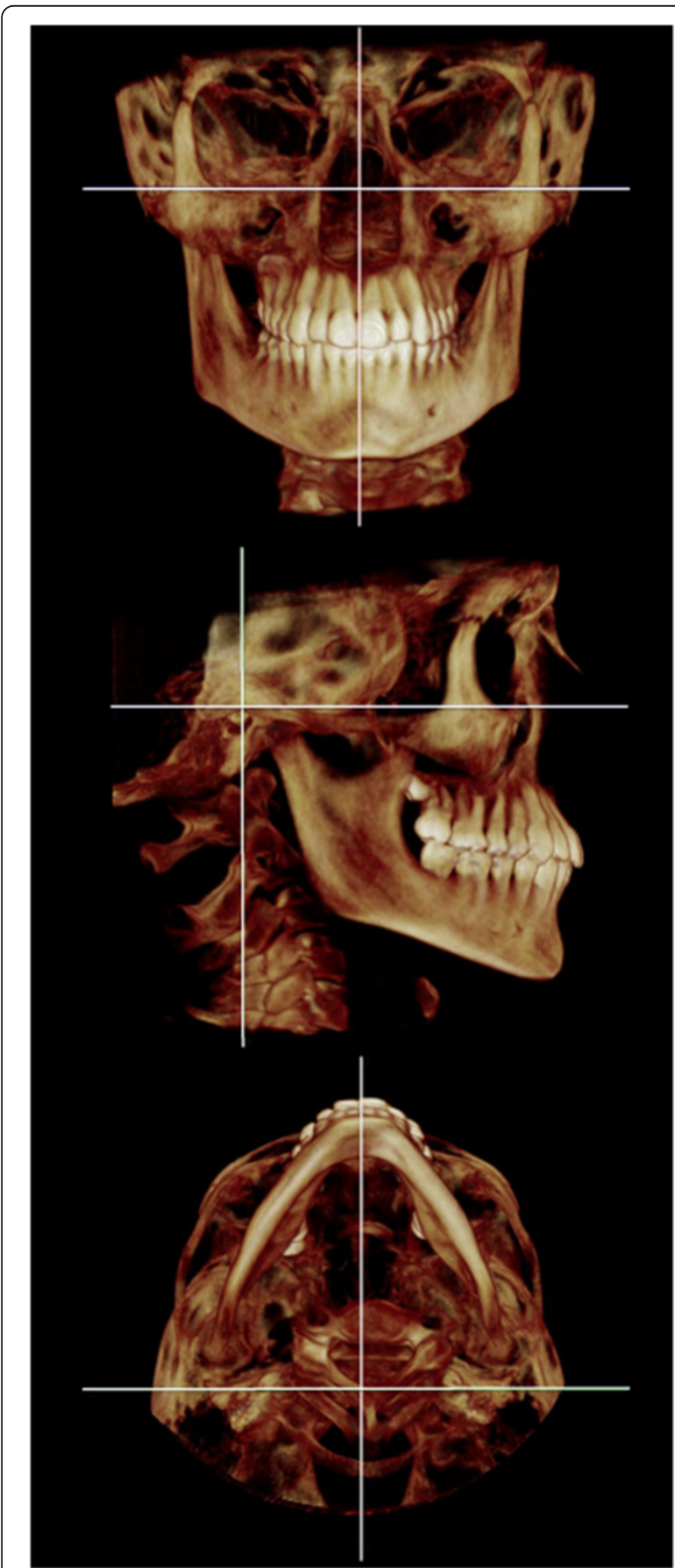

Figure 2 Volumetric renderings of the reference planes used in the study. axial plane $(y)$ was then constructed as a line connecting the most superior point of the external acoustic meatus (porion) with the most inferior point of the infraorbital rim (orbitale) on the right and left sides, which would correspond similarly to the Frankfort horizontal plane in 2D. Finally, the coronal plane $(z)$ was constructed using the transporionic line and fixed perpendicular to the axial and sagittal planes. Using modified orthodontic cephalometric landmarks, 34 anatomic landmarks were defined and digitized (Table 1) [12]. Coordinate data for each defined landmark was exported to an Excel database (Excel 2007, Microsoft, Redmond, WA, USA) and orthogonal, linear, and angular measurements were calculated.

\section{Measurements}

Orthogonal measurements were defined using sagittal, axial, and coronal planes and measured as perpendicular millimeter distances from the specific 3D landmark to each of the reference planes. Dental and dentoalveolar asymmetry, mandibular morphologic asymmetry, and condylar morphologic asymmetry were expressed as linear and angular measurements in millimeters and degrees, respectively (Table 2).

\section{Statistical analysis}

One investigator (DS) completed all measurements and intrarater reliability was assessed using the intraclass correlation coefficient (ICC) on a random sample of 10 patients, with each variable measured at two time points, 2 weeks apart. Once intrarater reliability was established, right-left and absolute measurements were analyzed using Student's $t$ tests for paired samples in the SPSS software program (version 14.0.1, SPSS, Chicago, IL, USA) with a significance of $p<0.05$.

\section{Results}

Intrarater reliability was measured, with high ICC values for each variable in all three reference planes as reported previously [12]. Measurements are presented as mean values \pm the standard deviation for each point described. For orthogonal differences relative to the axial plane (Table 3), glenoid fossa anterior (GlA) was found to be placed $0.47 \pm 1.08 \mathrm{~mm}$ superiorly on the right side relative to the left $(p<0.05)$. In addition, porion (Po) was also found to be positioned $0.37 \pm 0.88 \mathrm{~mm}$ superiorly on the right side $(p<0.05)$. Measurements to the coronal plane were all found to be non-significant (Table 4).

Significant differences were seen within the condylar and glenoid fossa points in the measurements to the sagittal plane (Table 5). Among the condylar measurements, the medial pole $(\mathrm{CdM})$, anterior pole $(\mathrm{CdA})$, and posterior pole $(\mathrm{CdP})$ were all found to be more laterally placed on the right side compared to the left, with a 
Table 1 Study landmarks and reference planes

\begin{tabular}{|c|c|c|c|c|c|c|}
\hline Landmarks & & & Definition & Sagittal slice & Axial slice & Coronal slice \\
\hline \multirow[t]{6}{*}{ Dental } & $M \times 1$ & $\begin{array}{l}\text { Maxillary central } \\
\text { incisors }\end{array}$ & $\begin{array}{l}\text { Incisal contact point of the maxillary } \\
\text { central incisors }\end{array}$ & Inferior-most point & Contact point & Incisal embrasure \\
\hline & Md1 & $\begin{array}{l}\text { Mandibular central } \\
\text { incisors }\end{array}$ & $\begin{array}{l}\text { Incisal contact point of the mandibular } \\
\text { central incisors }\end{array}$ & Inferior-most point & Contact point & Incisal embrasure \\
\hline & $M \times 3_{R}$ and $M \times 3_{L}$ & Maxillary canine & Cusp tip of the maxillary canine & Inferior-most point & First point that appears & Inferior-most point \\
\hline & $M d 3_{R}$ and $M \times 3_{L}$ & Mandibular canine & Cusp tip of the mandibular canine & Superior-most point & First point that appears & Superior-most point \\
\hline & $M \times \sigma_{R}$ and $M \times \sigma_{L}$ & Maxillary first molar & $\begin{array}{l}\text { Mesiobuccal cusp tip of the maxillary } \\
\text { first molar }\end{array}$ & Inferior-most point & First point that appears & Middle-inferior-most point \\
\hline & $M d \sigma_{R}$ and $M \times \sigma_{L}$ & Mandibular first molar & $\begin{array}{l}\text { Buccal groove of the mandibular } \\
\text { first molar }\end{array}$ & $\begin{array}{l}\text { Inferior-most point between } \\
\text { the buccal cusps }\end{array}$ & First point that appears & $\begin{array}{l}\text { Superior-most point in line } \\
\text { with the buccal cusps }\end{array}$ \\
\hline \multirow[t]{5}{*}{ Midface } & ANS & Anterior nasal spine & $\begin{array}{l}\text { The most anterior midpoint of the } \\
\text { anterior nasal spine of the maxilla }\end{array}$ & Lateral-most point & Superior-most point & First point that appears \\
\hline & PNS & Posterior nasal spine & $\begin{array}{l}\text { The most posterior midpoint of the } \\
\text { posterior nasal spine of the palatine bone }\end{array}$ & Lateral-most point & Inferior-most point & First point that appears \\
\hline & $\mathrm{Or}_{\mathrm{R}}$ and $\mathrm{Or}_{\mathrm{L}}$ & Orbitale & $\begin{array}{l}\text { The most inferior point on the infraorbital } \\
\text { rim of the maxilla }\end{array}$ & $\begin{array}{l}\text { Inferior-most point of the } \\
\text { infraorbital rim }\end{array}$ & Anterior-most point & $\begin{array}{l}\text { Inferior-most point of the } \\
\text { infraorbital rim }\end{array}$ \\
\hline & $F Z S_{R}$ and $F Z S_{L}$ & $\begin{array}{l}\text { Frontozygomatic } \\
\text { suture }\end{array}$ & $\begin{array}{l}\text { The most superior and medial point on } \\
\text { the frontozygomatic suture }\end{array}$ & Superior-most point & Anterior-most point & Medial-superior most point \\
\hline & $F P M_{R}$ and $F P M_{L}$ & $\begin{array}{l}\text { Frontal process of } \\
\text { maxilla }\end{array}$ & $\begin{array}{l}\text { Intersection of the frontal process of } \\
\text { the maxilla, frontal bone and lacrimal bone }\end{array}$ & Superior-most point & Anterior-most point & Medial-superior most point \\
\hline \multirow[t]{8}{*}{ Mandible } & $\mathrm{Me}$ & Menton & $\begin{array}{l}\text { The most inferior midpoint of the chin } \\
\text { on the outline of the mandibular symphysis }\end{array}$ & Inferior-most point & First point that appears & $\begin{array}{l}\text { Middle-most point along } \\
\text { the inferior border }\end{array}$ \\
\hline & $\mathrm{Pg}$ & Pogonion & $\begin{array}{l}\text { The most anterior midpoint of the chin } \\
\text { on the outline of the mandibular symphysis }\end{array}$ & Inferior-most point & Superior-most point & First point that appears \\
\hline & $\mathrm{Go}_{R}$ and $\mathrm{Go}_{\mathrm{L}}$ & Gonion & $\begin{array}{l}\text { The midpoint on the angle of the mandible, } \\
\text { half way between the corpus and ramus }\end{array}$ & $\begin{array}{l}\text { Middle-most point along the } \\
\text { angle of the mandible }\end{array}$ & Middle-inferior-most point & Middle-inferior-most point \\
\hline & $\mathrm{CdS}_{R}$ and $\mathrm{CdS}_{L}$ & Condyle superior & $\begin{array}{l}\text { The most superior point of the condylar } \\
\text { head }\end{array}$ & Superior-most point & First point that appears & Superior-most point \\
\hline & $\mathrm{CdL}_{R}$ and $\mathrm{CdL}_{\mathrm{L}}$ & Condyle lateral pole & $\begin{array}{l}\text { The most lateral point of the condylar } \\
\text { head }\end{array}$ & First point that appears & $\begin{array}{l}\text { Lateral-most point of the widest } \\
\text { section of the condyle }\end{array}$ & Lateral-most point \\
\hline & $\mathrm{CdM}_{\mathrm{R}}$ and $\mathrm{CdM_{L }}$ & Condyle medial pole & $\begin{array}{l}\text { The most medial point of the condylar } \\
\text { head }\end{array}$ & First point that appears & $\begin{array}{l}\text { Medial-most point of the widest } \\
\text { section of the condyle }\end{array}$ & Medial-most point \\
\hline & $\mathrm{CdA}_{R}$ and $\mathrm{CdA} \mathrm{A}_{\mathrm{L}}$ & Condyle anterior & $\begin{array}{l}\text { The most anterior point of the condylar } \\
\text { head }\end{array}$ & Anterior-most point & $\begin{array}{l}\text { Middle-most point on the anterior } \\
\text { surface of the widest section of } \\
\text { the condyle }\end{array}$ & Medial-most point \\
\hline & $\mathrm{CdP}_{\mathrm{R}}$ and $\mathrm{CdA_{L }}$ & Condyle posterior & $\begin{array}{l}\text { The most posterior point of the condylar } \\
\text { head }\end{array}$ & Posterior-most point & $\begin{array}{l}\text { Middle-most point on the posterior } \\
\text { surface of the widest section of } \\
\text { the condyle }\end{array}$ & N/A \\
\hline
\end{tabular}


Table 1 Study landmarks and reference planes (Continued)

Temporal bone $G S_{R}$ and $G I S_{L} \quad$ Glenoid fossa superior The most superior point of the glenoid

Superior-most poin

First point that appears

Superior-most point fossa of the temporal bone

$G I A_{R}$ and $G I A_{L} \quad$ Glenoid fossa Anterior The most inferior point of the articular eminence of the temporal bone

Inferior-most point on the articular eminence

Anterior-most point

Superior-most point

$\mathrm{PO}_{\mathrm{R}}$ and $\mathrm{PO}_{\mathrm{L}} \quad$ Porion

The most superior point of the external

Superior-most point of the

external acoustic meatus

First point that appears

Superior-most point of the external acoustic meatus

Reference planes

Axial plane

A plane that connects the most superior point of the external acoustic meatus with the most inferior point of the infraorbital rim on the right and left sides

Sagittal plane

A plane constructed using paired midfacial anatomic structures (eg., the orbits, frontal process of the maxilla, frontozygomatic suture)

Coronal plane

A plane constructed from the transporionic line 
Table 2 Definition of measurements

\begin{tabular}{|c|c|c|}
\hline & Variable & Definition \\
\hline \multirow[t]{6}{*}{ Dental } & A-P molar differential (mm) & The difference of $M \times 6(z)$ and $M d \sigma(z)$ \\
\hline & Midline differential (mm) & The absolute difference of $M \times 1(x)$ and $M d 1(x)$ \\
\hline & Overbite (mm) & Mx1 (y) minus Md1 (y) \\
\hline & Overjet (mm) & $\operatorname{Mx} 1(z)$ minus $M d 1(z)$ \\
\hline & Maxillary arch length (mm) & Distance $(x, y, z)$ between $M \times 6$ and $M \times 1$ \\
\hline & Mandibular arch length (mm) & Distance $(x, y, z)$ between $M d 6$ and $M \times 1$ \\
\hline Midface & Palatal plane to the sagittal plane $\left({ }^{\circ}\right)$ & Angulation $(x, z)$ between ANS-PNS and the sagittal plane \\
\hline \multirow[t]{10}{*}{ Mandibular } & Mandibular length in 3D (mm) & Distance $(x, y, z)$ between $C d S$ and $\mathrm{Pg}$ \\
\hline & Mandibular length in 2D (mm) & Distance $(y, z)$ between $\mathrm{CdS}$ and $\mathrm{Pg}$ \\
\hline & Ramus height in 3D (mm) & Distance $(x, y, z)$ between $C d S$ and Go \\
\hline & Ramus height in 2D (mm) & Distance $(y, z)$ between $\mathrm{CdS}$ and Go \\
\hline & Corpus length in 3D (mm) & Distance $(x, y, z)$ between Go and Pg \\
\hline & Corpus length in 2D (mm) & Distance $(y, z)$ between $\mathrm{Go}$ and $\mathrm{Pg}$ \\
\hline & Gonial angle $\left(^{\circ}\right)$ & Angulation $(y, z)$ between $\mathrm{CdS}, \mathrm{Go}$, and $\mathrm{Pg}$ \\
\hline & Mandibular plane angle $\left({ }^{\circ}\right)$ & Angulation $(y, z)$ between Go-Pg and the Frankfort horizontal \\
\hline & Ramus inclination to the sagittal plane $\left(^{\circ}\right)$ & Angulation $(x, y)$ between $\mathrm{CdL}-\mathrm{Go}$ and the sagittal plane \\
\hline & Dental and chin inclination $\left(^{\circ}\right)$ & Angulation $(x, y)$ between Md1-Me and the sagittal plane \\
\hline \multirow[t]{8}{*}{ Condylar } & Mediolateral diameter of condylar head in 3D (mm) & Distance $(x, y, z)$ between $C d L$ and $C d M$ \\
\hline & Mediolateral diameter of condylar head in 2D (mm) & Distance $(x, y)$ between $C d L$ and $C d M$ \\
\hline & Anteroposterior diameter of condylar head in 3D $(\mathrm{mm})$ & Distance $(x, y, z)$ between $C d A$ and $C d P$ \\
\hline & Anteroposterior diameter of condylar head in 2D $(\mathrm{mm})$ & Distance $(y, z)$ between $C d A$ and $C d P$ \\
\hline & Superior joint space in 3D (mm) & Distance $(x, y, z)$ between $C d S$ and GIS \\
\hline & Superior joint space in 2D (mm) & Distance $(x, y)$ between $\mathrm{CdS}$ and GIS \\
\hline & Condylar head inclination to the coronal plane $\left(^{\circ}\right)$ & Angulation $(x, z)$ between $\mathrm{CdL}-\mathrm{CdM}$ and the coronal plane \\
\hline & Condylar head inclination to the axial plane $\left(^{\circ}\right)$ & Angulation $(x, y)$ between $C d L-C d M$ and the axial plane \\
\hline
\end{tabular}

Table 3 Orthogonal left-right differences from axial plane

\begin{tabular}{|c|c|c|c|c|c|c|}
\hline & \multirow[t]{2}{*}{ Variable } & \multirow[t]{2}{*}{ Mean } & \multirow[t]{2}{*}{ SD } & \multicolumn{2}{|c|}{$95 \%$ confidence interval } & \multirow[t]{2}{*}{$p$ value } \\
\hline & & & & Lower & Upper & \\
\hline \multirow[t]{4}{*}{ Dental } & Mx3 $(y)$ to the axial plane $(\mathrm{mm})$ & -0.11 & 0.96 & -0.46 & 0.25 & 0.55 \\
\hline & Md3 $(y)$ to the axial plane $(\mathrm{mm})$ & 0.00 & 0.62 & -0.24 & 0.23 & 0.98 \\
\hline & Mx6 (y) to the axial plane $(\mathrm{mm})$ & 0.12 & 0.90 & -0.22 & 0.46 & 0.47 \\
\hline & Md6 $(y)$ to the axial plane $(\mathrm{mm})$ & -0.01 & 0.88 & -0.34 & 0.32 & 0.95 \\
\hline \multirow[t]{2}{*}{ Midface } & Or $(y)$ to the axial plane $(\mathrm{mm})$ & -0.09 & 0.75 & -0.37 & 0.19 & 0.52 \\
\hline & Go $(y)$ to the axial plane $(\mathrm{mm})$ & 0.5 & 1.43 & -0.03 & 1.03 & 0.07 \\
\hline \multirow[t]{5}{*}{ Mandible } & $\mathrm{CdS}(\mathrm{y})$ to the axial plane $(\mathrm{mm})$ & -0.22 & 0.93 & -0.56 & 0.13 & 0.21 \\
\hline & $\mathrm{CdL}(\mathrm{y})$ to the axial plane $(\mathrm{mm})$ & 0.03 & 1.12 & -0.39 & 0.45 & 0.9 \\
\hline & $\mathrm{CdM}(y)$ to the axial plane $(\mathrm{mm})$ & -0.14 & 1.07 & -0.54 & 0.26 & 0.49 \\
\hline & $\mathrm{CdA}(\mathrm{y})$ to the axial plane $(\mathrm{mm})$ & -0.02 & 1.01 & -0.4 & 0.36 & 0.91 \\
\hline & $\mathrm{CdP}(\mathrm{y})$ to the axial plane $(\mathrm{mm})$ & -0.05 & 1.02 & -0.43 & 0.33 & 0.79 \\
\hline \multirow[t]{3}{*}{ Temporal bone } & GIS $(y)$ to the axial plane $(\mathrm{mm})$ & -0.12 & 0.76 & -0.4 & 0.17 & 0.41 \\
\hline & $\mathrm{GIA}(\mathrm{y})$ to the axial plane $(\mathrm{mm})$ & -0.47 & 1.08 & -0.87 & -0.06 & $0.025^{*}$ \\
\hline & Po $(y)$ to the axial plane (mm) & -0.37 & 0.88 & -0.7 & -0.04 & $0.03^{*}$ \\
\hline
\end{tabular}

${ }^{*} p<0.05$. 
Table 4 Orthogonal left-right differences from coronal plane

\begin{tabular}{|c|c|c|c|c|c|c|}
\hline & \multirow[t]{2}{*}{ Variable } & \multirow[t]{2}{*}{ Mean } & \multirow[t]{2}{*}{ SD } & \multicolumn{2}{|c|}{ 95\% confidence interval } & \multirow[t]{2}{*}{$p$ value } \\
\hline & & & & Lower & Upper & \\
\hline \multirow[t]{4}{*}{ Dental } & Mx3 (z) to the coronal plane (mm) & 0.00 & 0.94 & -0.35 & 0.35 & 0.94 \\
\hline & Md3 (z) to the coronal plane (mm) & -0.01 & 0.77 & -0.30 & 0.27 & 0.93 \\
\hline & Mx6 (z) to the coronal plane (mm) & 0.03 & 1.00 & -0.34 & 0.41 & 0.86 \\
\hline & Md6 (z) to the coronal plane (mm) & 0.00 & 0.98 & -0.37 & 0.36 & 0.99 \\
\hline \multirow[t]{2}{*}{ Midface } & Or $(z)$ to the coronal plane $(\mathrm{mm})$ & -0.02 & 1.48 & -0.58 & 0.53 & 0.93 \\
\hline & Go $(z)$ to the coronal plane $(\mathrm{mm})$ & 0.06 & 1.66 & -0.56 & 0.68 & 0.84 \\
\hline \multirow[t]{5}{*}{ Mandible } & $\mathrm{CdS}(\mathrm{z})$ to the coronal plane $(\mathrm{mm})$ & 0.10 & 2.35 & -0.78 & 0.97 & 0.82 \\
\hline & $\mathrm{CdL}(\mathrm{z})$ to the coronal plane $(\mathrm{mm})$ & 0.02 & 2.12 & -0.77 & 0.81 & 0.96 \\
\hline & $\mathrm{CdM}(\mathrm{z})$ to the coronal plane $(\mathrm{mm})$ & 0.13 & 2.33 & -0.74 & 1.00 & 0.77 \\
\hline & $\mathrm{CdA}(\mathrm{z})$ to the coronal plane $(\mathrm{mm})$ & -0.54 & 2.11 & -1.32 & 0.25 & 0.17 \\
\hline & $\mathrm{CdP}(z)$ to the coronal plane $(\mathrm{mm})$ & -0.07 & 2.01 & -0.82 & 0.68 & 0.84 \\
\hline \multirow[t]{3}{*}{ Temporal bone } & GIS $(z)$ to the coronal plane $(\mathrm{mm})$ & -0.08 & 2.39 & -0.97 & 0.81 & 0.86 \\
\hline & GIA (z) to the coronal plane (mm) & -0.82 & 2.24 & -1.65 & 0.02 & 0.06 \\
\hline & Po (z) to the coronal plane $(\mathrm{mm})$ & 0.19 & 1.72 & -0.45 & 0.83 & 0.54 \\
\hline
\end{tabular}

discrepancy of $0.62 \pm 1.28 \mathrm{~mm}$ for $\mathrm{CdM}(p<0.05), 1.34 \pm$ $1.47 \mathrm{~mm}$ for CdA $(p<0.001)$, and $0.9 \pm 1.51 \mathrm{~mm}$ for $\mathrm{CdP}$ $(p<0.01)$. The GlA was also more laterally placed, by $1.73 \pm 1.52 \mathrm{~mm}$, on the right side relative to the left side $(p<0.001)$.

Midline structures were also measured to the sagittal plane (Table 6). Posterior nasal spine (PNS) was found to be $0.22 \pm 0.54 \mathrm{~mm}$ to the right of the sagittal plane. No significance was noted with other midline structures.
For absolute measurements, distances between two landmarks on each side were measured and the difference compared between the right and left sides (Table 7). Dental midline differential (MLD), defined as the absolute difference between the incisal embrasure of the maxillary central incisors $(\mathrm{Mx} 1)$ and the incisal embrasure of the mandibular incisors (Md1) from the sagittal plane, showed a significant discrepancy of $0.15 \pm 0.20 \mathrm{~mm}(p<0.0001)$. Maxillary (MXA) and mandibular (MDA) arch lengths

Table 5 Orthogonal left-right differences from sagittal plane

\begin{tabular}{|c|c|c|c|c|c|c|}
\hline & \multirow[t]{2}{*}{ Variable } & \multirow[t]{2}{*}{ Mean } & \multirow[t]{2}{*}{ SD } & \multicolumn{2}{|c|}{$95 \%$ confidence interval } & \multirow[t]{2}{*}{$p$ value } \\
\hline & & & & Lower & Upper & \\
\hline \multirow[t]{4}{*}{ Dental } & Mx3 $(x)$ to the saggital plane $(\mathrm{mm})$ & -0.02 & 1.11 & -0.43 & 0.40 & 0.94 \\
\hline & Md3 $(x)$ to the saggital plane $(\mathrm{mm})$ & -0.25 & 1.46 & -0.79 & 0.30 & 0.36 \\
\hline & Mx6 $(x)$ to the saggital plane $(\mathrm{mm})$ & 0.25 & 1.13 & -0.17 & 0.67 & 0.24 \\
\hline & Md6 $(x)$ to the saggital plane $(\mathrm{mm})$ & 0.29 & 1.07 & -0.11 & 0.69 & 0.16 \\
\hline \multirow[t]{2}{*}{ Midface } & Or $(x)$ to the saggital plane $(\mathrm{mm})$ & -0.05 & 1.70 & -0.69 & 0.58 & 0.87 \\
\hline & Go $(x)$ to the saggital plane $(\mathrm{mm})$ & 0.48 & 1.89 & -0.22 & 1.19 & 0.17 \\
\hline \multirow[t]{5}{*}{ Mandible } & $\mathrm{CdS}(x)$ to the saggital plane $(\mathrm{mm})$ & -0.19 & 1.81 & -0.86 & 0.49 & 0.57 \\
\hline & $\mathrm{CdL}(x)$ to the saggital plane $(\mathrm{mm})$ & -0.55 & 1.56 & -1.14 & 0.03 & 0.06 \\
\hline & $\mathrm{CdM}(\mathrm{x})$ to the saggital plane $(\mathrm{mm})$ & -0.62 & 1.28 & -1.10 & -0.14 & $0.013^{*}$ \\
\hline & $\mathrm{CdA}(x)$ to the saggital plane $(\mathrm{mm})$ & -1.34 & 1.47 & -1.89 & -0.80 & $0.0001^{* * *}$ \\
\hline & $\mathrm{CdP}(x)$ to the saggital plane $(\mathrm{mm})$ & -0.90 & 1.51 & -1.47 & -0.34 & $0.003^{* *}$ \\
\hline \multirow[t]{3}{*}{ Temporal bone } & GIS $(x)$ to the saggital plane $(\mathrm{mm})$ & 0.24 & 1.54 & -0.33 & 0.81 & 0.4 \\
\hline & GIA $(x)$ to the saggital plane $(\mathrm{mm})$ & -1.73 & 1.52 & -2.30 & -1.16 & $0.0001^{* * *}$ \\
\hline & Po $(x)$ to the saggital plane $(\mathrm{mm})$ & -0.35 & 1.66 & -0.97 & 0.27 & 0.25 \\
\hline
\end{tabular}


Table 6 Orthogonal measurements of midline structures to sagittal plane

\begin{tabular}{|c|c|c|c|c|c|c|}
\hline & \multirow[t]{2}{*}{ Variable } & \multirow[t]{2}{*}{ Mean } & \multirow[t]{2}{*}{ SD } & \multicolumn{2}{|c|}{ 95\% confidence interval } & \multirow[t]{2}{*}{$p$ value } \\
\hline & & & & Lower & Upper & \\
\hline \multirow[t]{2}{*}{ Dental } & Mx1 $(x)$ to the saggital plane $(\mathrm{mm})$ & -0.11 & 0.51 & -0.3 & 0.09 & 0.26 \\
\hline & Md $1(x)$ to the saggital plane $(\mathrm{mm})$ & -0.11 & 0.56 & -0.32 & 0.1 & 0.29 \\
\hline \multirow[t]{2}{*}{ Midface } & ANS $(x)$ to the saggital plane $(\mathrm{mm})$ & -0.16 & 0.48 & -0.34 & 0.02 & 0.08 \\
\hline & PNS $(x)$ to the saggital plane $(\mathrm{mm})$ & -0.22 & 0.54 & -0.43 & -0.02 & $0.032^{*}$ \\
\hline \multirow[t]{2}{*}{ Mandible } & Me $(x)$ to the saggital plane $(\mathrm{mm})$ & 0.11 & 0.68 & -0.14 & 0.36 & 0.38 \\
\hline & $\mathrm{Pg}(x)$ to the saggital plane $(\mathrm{mm})$ & 0.2 & 0.67 & -0.05 & 0.45 & 0.11 \\
\hline
\end{tabular}

${ }^{*} p<0.05$.

were found to be longer on the left side $(p<0.05)$, with the MXA left-right differential being $0.28 \pm 0.66 \mathrm{~mm}$ and MDA equivalent to $0.33 \pm 0.68 \mathrm{~mm}$. Ramus height, defined as the distance between the most superior point of the condylar head (CdS) and gonion (Go), was found to be significantly greater on the right side $(p<0.05)$ using both 3D (RH3) and 2D (RH2) calculations. Absolute measurement differences between the left and right sides were $0.81 \pm 1.65$ for RH3 and $0.75 \pm 1.60 \mathrm{~mm}$ for RH2. From the frontal aspect, ramus inclination (RI), measured as the angulation between most lateral point on the condylar head $(\mathrm{CdL})$ and Go to the sagittal plane was significantly more obtuse on the right side by $1.22^{\circ} \pm 2.92^{\circ}(p<0.05)$.

\section{Discussion}

The primary objective of this study was to measure the degree of asymmetry in patients who were otherwise defined as symmetric by clinical and radiographic examinations. The findings of this study show that skeletal asymmetries, while minor, may exist in otherwise clinically symmetric patients, confirming previous studies using $2 \mathrm{D}$ imaging and photography $[6,13,14]$. With the advent of CBCT technology, these small discrepancies can be localized to distinct sites. This data alludes to the possibility that during even the most tightly coupled processes, minor rightleft discrepancies may be reflections of minute skeletal compensations that occur as growth is directed.

Table 7 Absolute measurements of left-right differences

\begin{tabular}{|c|c|c|c|c|c|}
\hline \multirow[t]{2}{*}{ Variable } & \multirow[t]{2}{*}{ Mean } & \multirow[t]{2}{*}{ SD } & \multicolumn{2}{|c|}{$95 \%$ confidence interval } & \multirow[t]{2}{*}{$p$ value } \\
\hline & & & Lower & Upper & \\
\hline A-P molar differential (mm) & 0.04 & 0.28 & -0.07 & 0.14 & 0.484 \\
\hline Midline differential (mm) & 0.15 & 0.20 & 0.07 & 0.23 & $0.000^{* * * *}$ \\
\hline Maxillary arch length (mm) & 0.28 & 0.66 & 0.04 & 0.53 & $0.025^{*}$ \\
\hline Mandibular arch length (mm) & 0.33 & 0.68 & 0.08 & 0.58 & $0.012^{*}$ \\
\hline Mandibular length in 3D (mm) & -0.43 & 1.53 & -1.00 & 0.14 & 0.132 \\
\hline Manibular length in 2D (mm) & -0.21 & 1.53 & -0.78 & 0.36 & 0.452 \\
\hline Ramus height in 3D (mm) & -0.81 & 1.65 & -1.42 & -0.19 & $0.012^{*}$ \\
\hline Ramus height in 2D (mm) & -0.75 & 1.60 & -1.34 & -0.15 & $0.016^{*}$ \\
\hline Corpus length in 3D (mm) & 0.09 & 1.27 & -0.38 & 0.57 & 0.690 \\
\hline Corpus length in 2D (mm) & 0.08 & 1.67 & -0.55 & 0.70 & 0.801 \\
\hline Gonial angle $\left(^{\circ}\right)$ & 0.48 & 2.48 & -0.44 & 1.40 & 0.297 \\
\hline Mandibular plane angle $\left(^{\circ}\right)$ & 0.57 & 1.66 & -0.06 & 1.19 & 0.073 \\
\hline Ramus inclination to the saggital plane $\left(^{\circ}\right)$ & -1.22 & 2.92 & -2.32 & -0.13 & $0.029^{*}$ \\
\hline Mediolateral diameter of the condylar head in 3D (mm) & 0.06 & 1.22 & -0.39 & 0.52 & 0.781 \\
\hline Mediolateral diameter of the condylar head in 2D (mm) & 0.07 & 1.22 & -0.38 & 0.52 & 0.752 \\
\hline Anteroposterior diameter of the condylar head in 3D (mm) & -0.24 & 0.85 & -0.55 & 0.08 & 0.141 \\
\hline Anteroposterior diameter of the condylar head in 2D (mm) & -0.23 & 0.86 & -0.55 & 0.09 & 0.149 \\
\hline Superior joint space in 3D (mm) & -0.03 & 0.78 & -0.32 & 0.26 & 0.820 \\
\hline Superior joint space in 2D (mm) & 0.08 & 0.63 & -0.16 & 0.31 & 0.505 \\
\hline
\end{tabular}

${ }^{*} p<0.05,{ }^{* * * *} p<0.0001$. 
The asymmetries from this sample of patients showed either a mild right-side predominance or a mild left-side deficiency in the auriculo-temporal and condylar regions. The glenoid fossa was more laterally displaced on the right side and, along with the porion, was more superior in relation to the axial plane compared to the left side. Additionally, the condylar points were all more laterally displaced and the ramus heights were longer on the right side in both $3 \mathrm{D}$ and $2 \mathrm{D}$. The ramus inclination was also more obtuse on the right side compared to the left, and the PNS point was shown to lie to the right of the midsagittal plane. The only measurements increased on the left side were maxillary and mandibular arch lengths. The slight right-side predominance seen in this study is consistent with a number of studies which have also shown an increased tendency for right side laterality, albeit with varying degrees of significance $[6,8,13,15,16]$.

While the MLD showed a minor discrepancy in the maxillary and mandibular midlines, it should be noted that the lateral positions of menton $(\mathrm{Me})$ and pogonion $(\mathrm{Pg})$ relative to the midsagittal plane were not significant. This suggests that other compensations are likely to have occurred which adapted to the increased laterality and different vertical positions of the glenoid fossa and condylar points.

The intricate biological processes that direct growth and result in skeletal asymmetries have yet to be fully dissected. In his classic work, Woo proposed that minor asymmetries were due to skeletal compensations for asymmetric growth of the brain [17] and Burke theorized that right-left discrepancies were adaptive changes in response to asymmetric muscular and masticatory function [18]. At the molecular level, a number of genes and factors have been associated with asymmetric growth, identified in models of severe asymmetry associated with such syndromes as hemifacial microsomia, craniosynostosis and craniofacial clefts [19]. While genes, like Msx1, Goosecoid, TWIST, and TCOF1 have been linked to a number of craniofacial syndromes, no single gene has been identified as the sole cause of the skeletal abnormalities [20-23]. It is possible that a number of genes found within similar chromosomal loci are involved in these syndromes due to compromise during the embryonic period. Protein factors such as IGF-I, BMP-2 and TGF- $\beta 1$ have been shown to be highly expressed in specific regions of the condylar cartilage in patients with condylar hyperplasia, a primary cause of skeletal asymmetry [24]. Proper functioning and regulation of these genes and factors is likely to promote normal symmetric growth. It is possible that minor, localized gene expression differences or altered growth factor activity may result in the small skeletal discrepancies noted in the normal patients in this study. Further research is needed in this area to better understand the complex biologic pathways involved in normal growth and to determine which molecular alterations lead to increased degrees of asymmetry in patients.

This study was the first of its kind to utilize CBCT to evaluate asymmetries in a normal, Class I, adolescent population. Previous studies in Class III patients have shown a tendency towards significant asymmetry, specifically with deviation of the lateral position of menton to the mid-sagittal plane when measured on PA cephalograms [25]. A study by Sievers and colleagues using CBCT imaging showed minor asymmetries in Class I and Class II patients using an asymmetry index (AI), a mathematical derivation which combined measurements from each landmark to the $x$-, $y$-, and $z$-planes [26]. The degree of AI was similar between both groups, which were characterized according to ANB angle. A recent study of 10 human dry skulls defined as exhibiting apparent symmetry were also shown to have minor asymmetries by CBCT analysis, with measurements highly accurate when compared to the gold standard, physical measurements [8]. In the same study, PA cephalograms where shown to have inconsistencies in measurements, likely due to the difficulty in visualizing key structures in the $2 \mathrm{D}$ view.

In addition to the skeletal component, the soft tissue plays an important role in asymmetry and requires further study. A number of studies have used standardized photographs and stereophotogrammetry to assess soft tissue asymmetry [16,18,27]. A hierarchy for anatomic landmarks has been previously established for constructing the soft tissue midline, with the natural dental midline and the tip of philtrum being most reliable for measuring soft tissue asymmetries in 2D [28]. The tip of the nose and soft tissue nasion have been shown to be less reliable in photographic measurements. The accuracy of soft tissue measurements with CBCT enables 1:1 accuracy and the ability to more clearly define soft tissue landmarks through superimposition on cranial structures [29]. Soft tissue asymmetry has yet to be measured in class I patients with CBCT, and this would help further understand the softtissue compensations that overcome the minor skeletal discrepancies we observed in this study.

There were a number of limitations of this study that should be considered. The right-left discrepancies detected in this sample of patients were very minor, with most less than $1.0 \mathrm{~mm}$. For this reason, there is potential for some of these differences to be attributed to methodological error. Firstly, correct orientation of the CBCT in all three planes could have been a source of error. The method of sequential reference plane selection, particularly the use of paired midfacial structures for the midsagittal plane, was based on previously published studies [30,31]. While the sagittal plane was selected first, images also had to be corrected for roll to ensure the paired midfacial structures were correctly aligned vertically. The axial plane was then aligned for pitch and 
perpendicular to the sagittal plane followed by the coronal plane which was perpendicular to the sagittal and coronal planes and the best fit to the transporionic line. The 'best fit' of the three planes was determined by a single examiner at one timepoint. While the ICC for intrarater measurements was high, any minor inaccuracy in orientation of the CBCT at the initial stage could have resulted in some of the measured right-left differences seen in this study.

Landmark identification was another potential source of error in this study. Previous studies have shown the mediolateral dimension to be the least reproducible of the three dimensions with regards to landmark selection $[26,32]$. Particular anatomic landmarks pose challenges due to variation in morphology and convexity, such as condylion, gonion, and porion and there can be a greater degree of variability in the selection as shown by intra- and interrater reliability measures $[33,34]$. It is possible that utilizing a volumetric rendering view in conjunction with multiplanar views, as was used in this study, may minimize the degree of landmark selection error [35]. A number of the landmarks showing significant differences in this study were associated with these morphological challenges and thus could be skewed to show a right-left predominance or lack of predominance based on landmark selection.

The findings of this study reveal that very minor asymmetries may exist in otherwise symmetric patients, confirming previous studies that suggest that these discrepancies are normal and may be a reflection of a homeostatic mechanism during growth and bone remodeling.

\section{Conclusions}

Minor asymmetries are present in all planes by $\mathrm{CBCT}$ analysis in a normal, adolescent population. The craniofacial complex may have a natural compensatory mechanism to control the size and shape of specific tissues in order to maintain functional symmetry and homeostasis. Further studies are needed to better understand the soft tissue component to asymmetries in this population of subjects.

\section{Competing interests}

The authors declare that they have no competing interests.

\begin{abstract}
Authors' contributions
DS carried out the study, collected the CBCT images, and made the measurements. TC drafted the manuscript and was involved in data analysis and final submission. FU was a primary advisor on the study and was involved in the design of the study and data analysis, as well as manuscript preparation. PR provided the CBCT records and was an advisor, meeting routinely on design and data collection. RN was an advisor on the study and involved in the manuscript preparation as well as guidance throughout the study on design and implementation. All authors read and approved the final manuscript.
\end{abstract}

\section{Acknowledgements}

We would like to thank Dr. Paul Rigali, Wallingford, CT and Dr. Carl Roy, Virginia Beach, VA for providing the CBCT data for this study and to Dr.
William P. Neace former Assistant Professor in the Department of Psychology at the University of Hartford, Hartford, CT for performing the statistical analyses.

\section{Disclosure}

The authors would like to emphasize that the CBCT data analyzed in this study was acquired using existing records from two private offices. We in no way intend to promote the routine acquisition of $C B C T$ images in orthodontic patients

\section{Author details}

'Private Practice, Miami, FL, USA. ${ }^{2}$ Division of Orthodontics, Department of Craniofacial Sciences, University of Connecticut, School of Dental Medicine, 263 Farmington Avenue, Farmington CT 06030, USA. ${ }^{3}$ Private Practice, Woodstock, VT, USA. ${ }^{4}$ Department of Craniofacial Sciences, Alumni Endowed Chair, University of Connecticut, School of Dental Medicine, Farmington CT 06030, USA.

Received: 10 September 2013 Accepted: 16 January 2014

Published online: 01 April 2014

\section{References}

1. Proffit WR, White RP, Sarver DM. Contemporary treatment of dentofacial deformity. 4th ed. Maryland Heights, Missouri: Mosby; 2003.

2. Bishara SE, Burkey PS, Kharouf JG. Dental and facial asymmetries: a review. Angle Orthod. 1994; 64(2):89-98. doi:10.1043/0003-3219(1994)064<0089: DAFAAR $>2.0 . C O ; 2$.

3. Pirttiniemi P. Normal and increased functional asymmetries in the craniofacial area. Acta Odontol Scand. 1998; 56(6):342-5.

4. Burstone CJ. Diagnosis and treatment planning of patients with asymmetries. Semin Orthod. 1998; 4(3):153-64

5. Sheats RD, McGorray SP, Musmar Q, Wheeler TT, King GJ. Prevalence of orthodontic asymmetries. Semin Orthod. 1998; 4(3):138-45.

6. Shah SM, Joshi MR. An assessment of asymmetry in the normal craniofacial complex. Angle Orthod. 1978; 48(2):8-141. doi:10.1043/0003-3219(1978)048<0141: AAOAIT>2.0.CO;2.

7. Nanda R, Snodell SF, Bollu P. Transverse growth of maxilla and mandible. Semin Orthod. 2012; 18(2):100-17. doi:10.1053/j.sodo.2011.10.007.

8. de Moraes ME, Hollender LG, Chen CS, Moraes LC, Balducci I. Evaluating craniofacial asymmetry with digital cephalometric images and cone-beam computed tomography. Am J Orthod Dentofacial Orthop. 2011; 139(6):e523-31. doi:10.1016/.jajodo.2010.10.020.

9. AlHadidi A, Cevidanes LH, Mol A, Ludlow J, Styner M. Comparison of two methods for quantitative assessment of mandibular asymmetry using cone beam computed tomography image volumes. Dentomaxillofac Radiol. 2011: 40(6):351-7. doi:10.1259/dmfr/13993523.

10. Alhadidi A, Cevidanes LH, Paniagua B, Cook R, Festy F, Tyndall D. 3D quantification of mandibular asymmetry using the SPHARM-PDM tool box. Int I Comput Assist Radiol Surg. 2012; 7(2):265-71. doi:10.1007/s11548-011-0665-2.

11. Damstra J, Fourie Z, Ren Y. Evaluation and comparison of postero-anterior cephalograms and cone-beam computed tomography images for the detection of mandibular asymmetry. Eur J Orthod. 2013; 35(1):45-50. doi:10.1093/ejo/cjr045.

12. Sanders DA, Rigali PH, Neace WP, Uribe F, Nanda R. Skeletal and dental asymmetries in Class II subdivision malocclusions using cone-beam computed tomography. Am J Orthod Dentofacial Orthop. 2010; 138(5):542. e1-20; discussion -3. doi:10.1016/j.ajodo.2010.02.027.

13. Peck S, Peck L, Kataja M. Skeletal asymmetry in esthetically pleasing faces. Angle Orthod. 1991; 61(1):8-43. doi:10.1043/0003-3219(1991)061<0043: SAIEPF $>2.0 . \mathrm{CO} ; 2$

14. Vig PS, Hewitt AB. Asymmetry of the human facial skeleton. Angle Orthod. 1975; 45(2):9-125. doi:10.1043/0003-3219(1975)045<0125: AOTHFS>2.0.CO;2.

15. Farkas $L G$, Cheung G. Facial asymmetry in healthy North American Caucasians. An anthropometrical study. Angle Orthod. 1981; 51(1):7-70. doi:10.1043/0003-3219(1981)051<0070: FAlHNA>2.0.CO;2.

16. Haraguchi $\mathrm{S}$, Iguchi $Y$, Takada K. Asymmetry of the face in orthodontic patients. Angle Orthod. 2008; 78(3):421-6. doi:10.2319/022107-85.1.

17. Woo TL. On the asymmetry of the human skull. Biometrika. 1931; 22:21

18. Burke PH. Stereophotogrammetric measurement of normal facial asymmetry in children. Hum Biol. 1971; 43(4):536-48.

19. Kronmiller JE. Development of asymmetries. Semin Orthod. 1998; 4(3):134-7. 
20. el Ghouzzi V, Le Merrer M, Perrin-Schmitt F, Lajeunie E, Benit P, Renier D, Bourgeois P, Bolcato-Bellemin AL, Munnich A, Bonaventure J. Mutations of the TWIST gene in the Saethre-Chotzen syndrome. Nat Genet. 1997; 15(1):42-6. doi:10.1038/ng0197-42.

21. Kelberman D, Tyson J, Chandler DC, Mclnerney AM, Slee J, Albert D, Aymat A, Botma M, Calvert M, Goldblatt J, Haan EA, Laing NG, Lim J, Malcolm S, Singer SL, Winter RM, Bitner-Glindzicz M. Hemifacial microsomia: progress in understanding the genetic basis of a complex malformation syndrome. Hum Genet. 2001; 109(6):638-645. doi:10.1007/s00439-001-0626-X.

22. Satokata I, Maas R. Msx1 deficient mice exhibit cleft palate and abnormalities of craniofacial and tooth development. Nat Genet. 1994; 6(4):348-56. doi:10.1038/ng0494-348.

23. Su PH, Liu YF, Yu JS, Chen JY, Chen SJ, Lai YJ. Facial asymmetry and clinical manifestations in patients with novel insertion of the TCOF1 gene. Clin Genet. 2011; 82(5):460-5. doi:10.1111/j.1399-0004.2011.01765.x

24. Meng Q, Long X, Deng M, Cai H, Li J. The expressions of IGF-1, BMP-2 and TGF-beta1 in cartilage of condylar hyperplasia. J Oral Rehabil. 2011; 38(1):34-40. doi:10.1111/j.1365-2842.2010.02125.x.

25. Haraguchi S, Takada K, Yasuda Y. Facial asymmetry in subjects with skeletal Class III deformity. Angle Orthod. 2002; 72(1):28-35. doi:10.1043/0003-3219(2002)072<0028: FAISWS>2.0.CO;2.

26. Sievers MM, Larson BE, Gaillard PR, Wey A. Asymmetry assessment using cone beam CT. A Class I and Class II patient comparison Angle Orthod. 2012; 82(3):410-7. doi:10.2319/041711-271.1.

27. Severt TR, Proffit WR. The prevalence of facial asymmetry in the dentofacial deformities population at the University of North Carolina. Int J Adult Orthodon Orthognath Surg. 1997; 12(3):171-6.

28. Bidra AS, Uribe F, Taylor TD, Agar JR, Rungruanganunt P, Neace WP. The relationship of facial anatomic landmarks with midlines of the face and mouth. J Prosthet Dent. 2009; 102(2):94-103. doi:10.1016/S0022-3913(09)60117-7.

29. Cevidanes LH, Motta A, Proffit WR, Ackerman JL, Styner M. Cranial base superimposition for 3-dimensional evaluation of soft-tissue changes. Am J Orthod Dentofacial Orthop. 2010; 137(4 Suppl):S120-9. doi:10.1016/j. ajodo.2009.04.021.

30. Swennen GR, Schutyser F, Barth EL, De Groeve P, De Mey A. A new method of 3-D cephalometry Part I: the anatomic Cartesian 3-D reference system. J Craniofac Surg. 2006; 17(2):314-25.

31. van Vlijmen OJ, Berge SJ, Swennen GR, Bronkhorst EM, Katsaros C, KuijpersJagtman AM. Comparison of cephalometric radiographs obtained from cone-beam computed tomography scans and conventional radiographs. J Oral Maxillofac Surg. 2009; 67(1):92-7. doi:10.1016/j.joms.2008.04.025.

32. Ludlow JB, Gubler M, Cevidanes L, Mol A. Precision of cephalometric landmark identification: cone-beam computed tomography vs conventional cephalometric views. Am J Orthod Dentofacial Orthop. 2009; 136(3):312. e1-10; discussion -3. doi:10.1016/j.ajodo.2008.12.018.

33. Lagravere MO, Low C, Flores-Mir C, Chung R, Carey JP, Heo G, Major PW. Intraexaminer and interexaminer reliabilities of landmark identification on digitized lateral cephalograms and formatted 3-dimensional cone-beam computerized tomography images. Am J Orthod Dentofacial Orthop. 2010; 137(5):598-604. doi:10.1016/j.ajodo.2008.07.018.

34. Schlicher W, Nielsen I, Huang JC, Maki K, Hatcher DC, Miller AJ. Consistency and precision of landmark identification in three-dimensional cone beam computed tomography scans. Eur J Orthod. 2012; 34(3):263-75. doi:10.1093/ejo/cjq144.

35. Periago DR, Scarfe WC, Moshiri M, Scheetz JP, Silveira AM, Farman AG. Linear accuracy and reliability of cone beam CT derived 3-dimensional images constructed using an orthodontic volumetric rendering program. Angle Orthod. 2008; 78(3):387-95. doi:10.2319/122106-52.1.

\section{Submit your manuscript to a SpringerOpen ${ }^{\circ}$ journal and benefit from:}

- Convenient online submission

- Rigorous peer review

- Immediate publication on acceptance

- Open access: articles freely available online

- High visibility within the field

- Retaining the copyright to your article

Submit your next manuscript at $>$ springeropen.com 